РЕЗУЛЬТАТИ ЕКСПЕРИМЕНТАЛЬНОЇ ПІДГОТОВКИ МАЙБУТНІХ БАКАЛАВРІВ СПЕЦІАЛЬНОЇ ОСВІТИ ДО ВИКОРИСТАННЯ ЦИФРОВИХ ТЕХНОЛОГІЙ У ПРОФЕСІЙНІЙ ДІЯЛЬНОСТІ В УМОВАХ ІНКЛЮЗИВНОГО ОСВІТНЬОГО ПРОСТОРУ

\title{
RESULTS OF EXPERIMENTAL TRAINING OF FUTURE BACHELORS OF EDUCATION FOR THE USE OF DIGITAL TECHNOLOGIES IN PROFESSIONAL ACTIVITY
}

у статті акцентовано увагу на результатах експерименту щодо підготовки бакалаврів освіти до упровадження цифрових технологій у профресійній діяльності в умовах інклюзивного освітнього простору. Набуття високого рівня професійної підготовленості загалом та ї̈ складників цифррової грамотності та інформаційно-комунікативної компетентності забезпечує бакалавра спеціальної освіти здатністю вирішувати проблемні професійні ситуації, знаходити раціональні та ефективні шляхи розв'язання профресійних завдань, бути конкурентоспроможним на ринку праці. Це вимагає широкого використання ЦТ в умовах інклюзивного освітнього середовища закладу освіти. Під час експериментальної підготовки бакалаврів спеціальної освіти до упровадження ЦТ у професійній діяльності в умовах інклюзивного освітнього середовища було поєднано удосконалення змісту інформатичних та педагогічних дисциплін, ефрективні фрорми (такі як лекції-візуалізації; тренінги; майстер-класи від стейкхолдерів; семінари; лабораторні роботи; виробнича практика; практика з виготовлення мультимедійних матеріалів), методи (такі, як створення ситуації зацікавленості, проблемне навчання, інтерактивні, ігрові, проєктні) та засоби, залучено сучасні технології контролю, створено системи інноваційних мультимедійних засобів та цисрровий супровід освітнього процесу. Проведення експериментальної підготовки бакалаврів освіти до упровадження цифрових технологій у професійній діяльності в умовах інклюзивного освітнього простору вимагало проведення педагогічного експерименту, який передбачав порівняння рівнів за різними показниками бакалаврів спеціальної освіти контрольної та експериментальної груп. Ми обгрунтували три критерії: теоретичний, практичний і психологічний. їх показниками виступили здатність до розвитку у царині ЦТ для інклюзії, обсяг знань, цифрова обізнаність, уміння конструювання інклюзивного освітнього простору засобами ЦТ, самоаналіз. Педагогічний експеримент підтвердив доцільність запропонованої експериментальної підготовки бакалаврів спеціальної освіти до упровадження цифрових технологій у профресійній діяльності в умовах інклюзивного освітнього простору, що підтверджено статистичними методами.

Ключові слова: профресійна підготовка; бакалаври освіти; інклюзивний освітній про- стір; експеримент; критерії; рівні; цифррові технології.

The article focuses on the results of an experiment on the preparation of bachelors of education for the introduction of digital technologies in professional activities in an inclusive educational space. Acquiring a high level of professional training in general and its components of digital literacy and information and communication competence provides a bachelor of special education with the ability to solve problematic professional situations, the ability to find rational and effective ways to solve professional problems, the ability to be competitive in the labor market. This requires extensive use of CT in an inclusive educational environment. During the experimental preparation of bachelors of special education for the introduction of CT in professional activities in an inclusive educational environment, the improvement of the content of computer science and pedagogical disciplines, effective forms (such as lectures-visualizations; trainings; master classes from stakeholders; seminars; laboratory works; production practice (practice of making multimedia materials), methods (such as (creating a situation of interest, problembased learning, interactive, game, project) and tools, modern control technologies are involved, created systems of innovative multimedia tools and digital support of the educational process. preparation of bachelors of education for the introduction of digital technologies in professional activities in an inclusive educational space required a pedagogical experiment, which involved comparing the levels of different indicators of bachelors of special education control and experimental groups. We have substantiated three criteria: theoretical, practical and psychological. Their indicators were the ability to develop in the field of CT for inclusion, the amount of knowledge, digital awareness, the ability to construct an inclusive educational space by means of $C T$, introspection. The pedagogical experiment confirmed the expediency of the proposed experimental training of bachelors of special education for the introduction of digital technologies in professional activities in an inclusive educational space, which is confirmed by statistical methods.

Key words: professional training; bachelors of education; inclusive educational space; experiment; criteria; levels; digital technologies.
Постановка проблеми у загальному вигляді. Надзвичайно актуальною сьогодні $€$ проблема інклюзивного освітнього процесу учнів 3 особливими потребами, що вимагає інноваційного переосмислення професійної підготовки майбут- ніх бакалаврів спеціальної освіти. Цифровізація та інфрорматизація освітнього процесу створює особливий попит на компетентних, обізнаних, творчих, майстерних педагогів, які мають високий рівень здатності ефективно застосовувати 
набуті профресійні знання у практичній діяльності, не лише упроваджувати, але й створювати нові форми, методи роботи, засоби навчання в умовах інклюзивного освітнього середовища.

Водночас новітні тенденції соціуму вимагають розвитку системи освіти та підготовки майбутніх бакалаврів освіти на засадах цифрових технологій (ЦТ), створення та функціонування належного високотехнологічного та високоякісного інфрормаційно-освітнього середовища. Його значення останнім часом зростає і якісно впливає на процес фрормування та розвитку професійної культури майбутніх бакалаврів освіти. Набуття високого рівня профресійної підготовленості загалом та цифррової грамотності й інфрормаційно-комунікативної компетентності зокрема забезпечує бакалавра спеціальної освіти здатністю вирішувати проблемні профресійні ситуації, здатністю знаходити раціональні та ефективні шляхи розв'язання профресійних завдань, здатністю бути конкурентоспроможним на ринку праці. Це вимагає широкого використання ЦТ в умовах інклюзивного освітнього середовища закладу освіти.

Ці дві тенденції у професійній підготовці бакалаврів спеціальної освіти зумовлюють, 3 одного боку, необхідність істотних змін у освітньому процесі, а з іншого боку, вимагають підвищення рівня розвитку професійних компетентностей спеціальних педагогів. Педагогічні 3ВО мають докласти максимум зусиль для організації підготовки фрахівців-педагогів, рівень кваліфікації яких відповідає циорровим та технічним інноваціям, що здійснюються нині в галузі освіти. Отже, особливого значення набуває в сучасному інфрорматичному суспільстві удосконалення професійної підготовки бакалаврів спеціальної освіти у педагогічних 3 ВО через розвиток профресійних інтересів, ціннісних орієнтацій та мотивів, систему знань, умінь і навичок у галузі циоррових технологій, що заохочують майбутніх фрахівців до створення та використання циоррових інновацій в умовах інклюзивного освітнього середовища.

Аналіз останніх досліджень і публікацій. Особливості організації інклюзивного освітнього процесу, специфіка корекційно-розвивальної, корекційно-навчальної та корекційно-виховної діяльності спеціального педагога в умовах інклюзивної та спеціальної освіти представлено у дослідженнях Г. Бойко, Ю. Бойчук, І. Дмитрієва, А. Колупаєва, І. Мартиненко, Н. Пахомова, Т. Сак, Є. Синьова, Н. Софрій, А. Шевцов, Д. Шульженко та ін.

Проблеми застосування інформаційно-комунікаційних технологій у освітньому процесі закладів освіти різних рівнів висвітлено у дослідженях В. Бикова, В. Беспалька, Ю. Брановського, П. Гальперіна, Ю. Горошко, Т. Добутько, М. Жалдака, І. Ізвозчикової, А. Кузнецової, А. Кудіна, В. Клочко, В. Матросова, Ю. Машбиця, Н. Морзе,
М. Пригодій, С. Ракова, О. Торубари та інших. Ці роботи висвітлюють проблеми методологічних та психолого-педагогічних засад раціонального застосування IT у освітньому процесі, дидактичного потенціалу комп'ютерної та цифрової техніки та програмного забезпечення.

Зарубіжні та вітчизняні дослідники, такі як M. Ainscow, B. Cagran, J.-R. Kim, M. Schmidt, B. Бондар, В. Засенко, К. Косова, Г. Кумаріна, В. Липа, О. Мартинчук, Н. Савінова, Є. Синьова, М. Шеремет та інші, одностайно схиляються до думки, що істотною умовою існування та розвитку інклюзивного освітнього середовища $€$ профресійна підготовка компетентних спеціальних педагогів, які здатні професійно навчати дітей 3 особливими освітніми потребами із застосуванням цифрових технологій.

Виділення не вирішених раніше частин загальної проблеми. Одним зі знакових напрямів професійної підготовки майбутніх бакалаврів освіти до використання цифрових технологій у профресійній діяльності в умовах інклюзивного освітнього простору, який віддзеркалює реформування сучасного суспільства у напрямі розвитку циоррового та технічного забезпечення, $є$ інорорматизація освіти.

Для ефективного формування цифрової компетентності студентів педагогічного ЗВО необхідно враховувати міждисциплінарну інтеграцію освіти. Міждисциплінарна інтеграція як вища фрорма інтеграції змісту освіти є основою відбору змісту міждисциплінарного курсу, спрямованого на фрормування цифрової компетентності студентів педагогічного ЗВО [2]. На думку Р. Гуревича, до умов цифровізації освіти можна віднести: цифрове покоління студентів; створення законодавчої бази для цифровізації освіти; ресурсне забезпечення цифровізації освіти, що включає цифрове освітнє середовище освітньої організації; підготовку кадрового потенціалу цифрової освіти, володіння ІКТ-компетентністю, що включає цифрову грамотність; цифрові педагогічні технології та освітньо значущі цифрові технології [1].

Науковці вказують на важливість проблеми пошуку шляхів модернізації процесу професійної підготовки бакалаврів освіти відповідно до сучасних тенденцій розвитку освіти, важливість дослідження механізму, технологій такого впровадження на практиці [3; 4].

Під час реалізації процесу формування цифррової компетентності майбутніх педагогів доцільно:

- використовувати активні та інтерактивні фрорми і методи навчання;

- використовувати цифрові педагогічні технології (змішане навчання, мобільне навчання, технологія доповненої реальності, дистанційні освітні технології, гейміфрікація, електронне (онлайн) навчання тощо; 
- використовувати освітньо значущі цифрові технології (великі дані, системи розподіленого реєстру, штучний інтелект, компоненти робототехніки, технології бездротового зв'язку, технології віртуальної і доповненої реальності, технологію цифрового двійника, технології електронної ідентифікації й аутентиорікації, цифррові технології спеціалізованого освітнього призначення, інтернет речей),

- базуватися на використанні технічних засобів і спеціалізованого інтерактивного устаткування (ПК, ноутбуки, планшети, робототехнічні набори, інтерактивні дошки, електронні фрліпчарти, інтерактивна панель, інтерактивна пісочниця, інтерактивна підлога, інтерактивні куби та ін.) [5; 6; 7; 8].

Отже, нині у системі педагогічної освіти загалом і спеціальної зокрема $є$ низка суперечностей:

- між зростаючим впливом цифровізації на розвиток освіти в цілому, що породжує необхідність підвищення якості освітнього процесу, і недостатньою сорормованістю цифрової грамотності студентів педагогічного ЗВО для роботи в умовах циорровізації освіти;

- між необхідністю фрормування цифрової грамотності майбутніх педагогів при їх підготовці в умовах цифровізації освіти відповідно до вимог сучасних стандартів і неможливістю забезпечення в належній мірі фрормування цифррової грамотності студентів педагогічного ЗВО як майбутніх педагогів із застосуванням існуючих моделей і методик;

- між потребою інклюзивних освітніх організацій в педагогах 3 високим рівнем сформованості циоррової грамотності, що забезпечує успішне виконання педагогічної діяльності, і існуючим рівнем IKT-компетентності студентів педагогічного 3ВО, недостатнім для успішної реалізації майбутньої професійної діяльності.

Мета статті. Розглянути результати експерименту щодо підготовки бакалаврів спеціальної освіти до упровадження цифрових технологій у професійній діяльності в умовах інклюзивного освітнього простору.

Виклад основного матеріалу. Формувальний етап педагогічного експерименту відбувався протягом 2017-2020 рр. До контрольних груп (КГ) увійшло 93 студенти педагогічних університетів, які навчалися за традиційними технологіями. У експериментальну групу (ЕГ) включено 98 студентів педагогічних університетів, які навчалися за авторською моделлю. Нами досліджувався процес підготовки бакалаврів спеціальної освіти до упровадження цифрових технологій у професійній діяльності в умовах інклюзивного освітнього середовища.

Під час експериментальної підготовки бакалаврів спеціальної освіти до упровадження ЦТ у професійній діяльності в умовах інклюзивного освітнього середовища було поєднано удосконалення змісту інфрорматичних та педагогічних дисциплін, ефективні фрорми (такі, як лекції-візуалізації; тре- нінги; майстер-класи від стейкхолдерів; семінари; лабораторні роботи; виробнича практика; практика з виготовлення мультимедійних матеріалів), методи (такі, як (створення ситуації зацікавленості, проблемне навчання, інтерактивні, ігрові, проєктні) та засоби, залучено сучасні технології контролю, створено системи інноваційних мультимедійних засобів та циорровий супровід освітнього процесу.

Під час визначення рівнів готовності бакалаврів спеціальної освіти до упровадження цифрових технологій у професійній діяльності в умовах інклюзивного освітнього простору ми обґрунтували три критерії: теоретичний, практичний і психологічний. Їх показниками виступили здатність до розвитку у царині ЦТ для інклюзії, обсяг знань, цифрова обізнаність, уміння конструювання інклюзивного освітнього простору засобами ЦТ, самоаналіз.

Нами виділено чотири рівні готовності бакалаврів освіти до упровадження цифррових технологій у профресійній діяльності в умовах інклюзивного освітнього середовища:

- пасивний (низький рівень зацікавленості, здатностей, знань і умінь бакалаврів спеціальної освіти в галузі інорорматики, які можуть бути затребувані під час використання ЦТ в їхній майбутній профресійній діяльності);

- елементарний (середній рівень зацікавленості, здатностей, знань і умінь бакалаврів спеціальної освіти в галузі ЦТ, які можуть бути використані в їхній майбутній професійній діяльності);

- базовий (достатній рівень зацікавленості, здатностей, знань і умінь бакалаврів спеціальної освіти в галузі ЦТ, які можуть бути використанні в їхній майбутній професійній діяльності);

- високий (високий рівень зацікавленості, здатностей, знань і умінь бакалаврів спеціальної освіти в галузі інформатики, які можуть бути творчо при використанні ЦТ в їхній майбутній професійній діяльності).

Результати педагогічного експерименту за показником «Обсяг знань» наведено на рис. 1.

Загальні результати щодо кількісної характеристики «Цифрова обізнаність» студентів обох груп розподілилися таким чином (рис. 2). За діаграмою (рис. 2) можна припустити, що на початку експерименту вибірки статистично однакові.

Експериментальні результати щодо показника «Уміння конструювання інклюзивного освітнього простору засобами ЦТ» студентів обох груп наведено на рис. 3.

Одним із показників сфрормованості готовності бакалаврів освіти до упровадження цифрових технологій у професійній діяльності в умовах інклюзивного освітнього простору за психологічним критерієм визначено здатність до розвитку у царині ЦТ для інклюзії. Результати експериментального навчання за цим показником наведено на рис. 4 . 


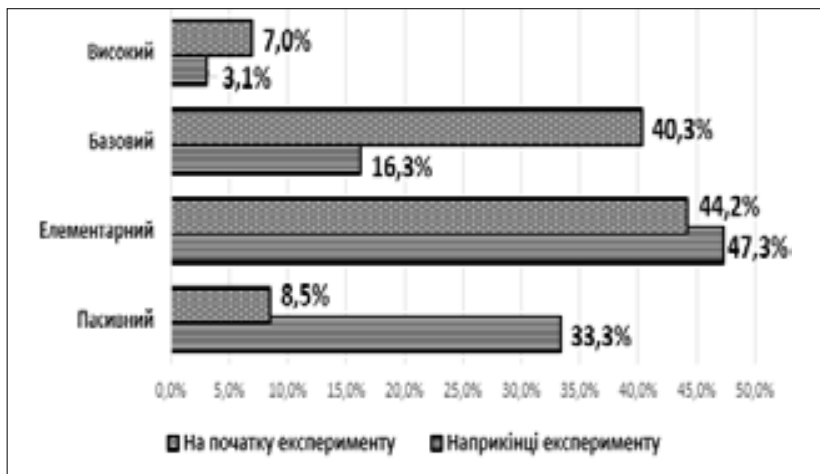

a)

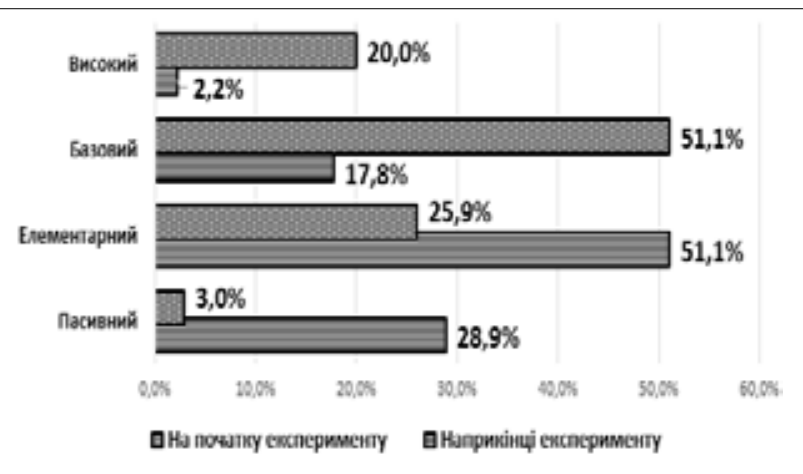

б)

Рис. 1. Діаграма рівнів на початку експерименту та після експерименту для КГ (а) та ЕГ (б)

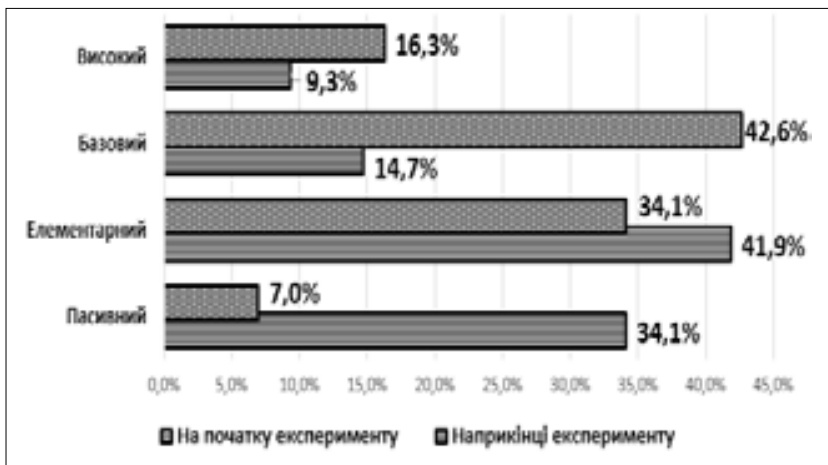

a)

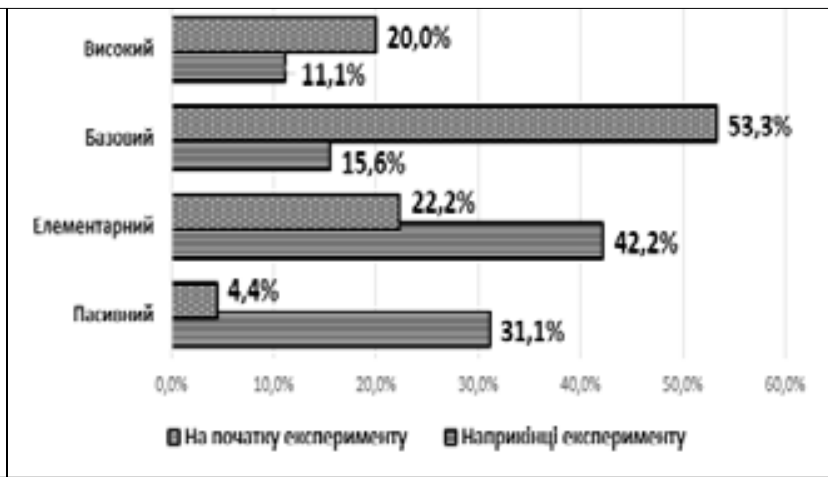

б)

Рис. 2. Діаграма рівнів на початку експерименту та після експерименту для КГ (а) та ЕГ (б)

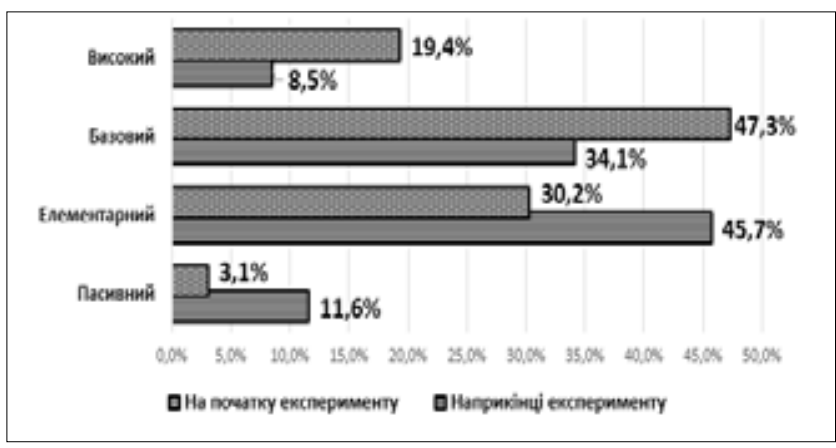

a)

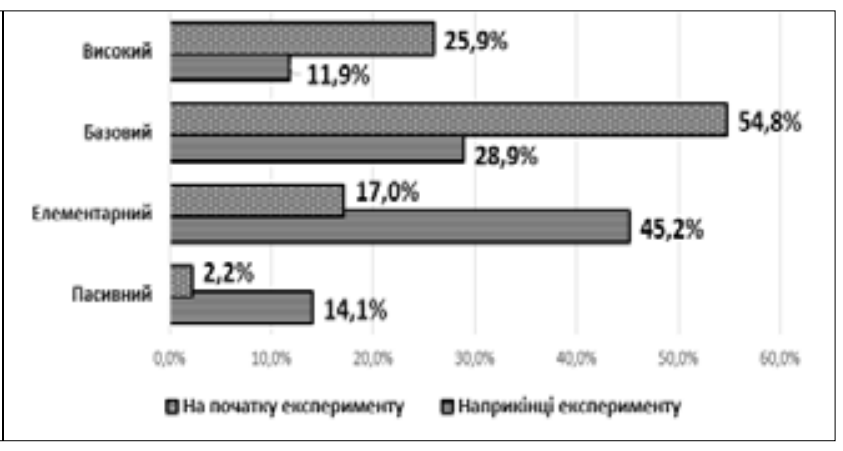

б)

Рис. 3. Діаграма рівнів на початку експерименту та після експерименту для КГ (а) та ЕГ (б)

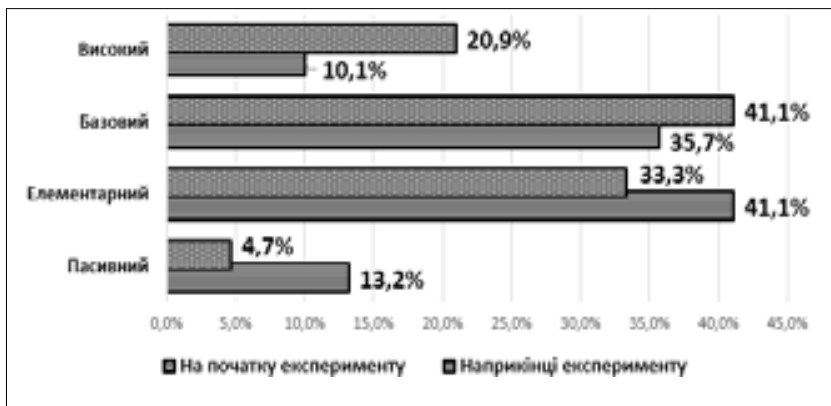

a)

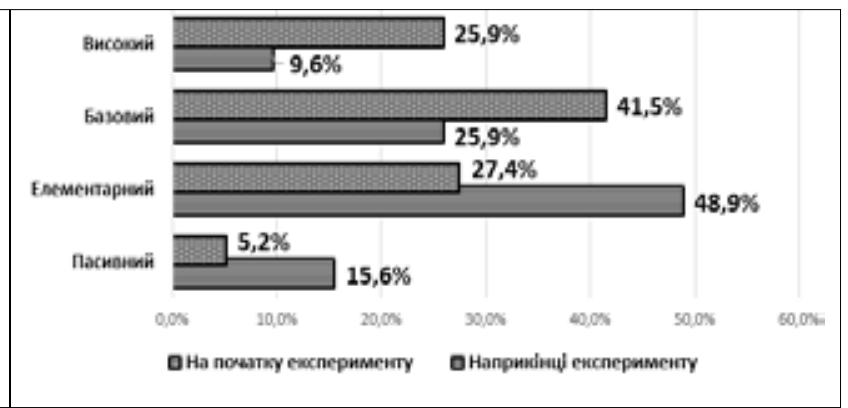

б)

Рис. 4. Діаграма рівнів на початку експерименту та після експерименту для КГ (а) та ЕГ (б) 
Розподіл учасників за рівнями на початку експерименту

Таблиця 1

\begin{tabular}{|c|c|c|c|c|c|c|c|}
\hline \multirow{3}{*}{ Рівні } & \multicolumn{3}{|c|}{ Контрольна група } & \multicolumn{3}{|c|}{ Експериментальна група } & \multirow{3}{*}{$\begin{array}{c}\text { Різниця } \\
\text { (ЕГ - КГ } \\
\text { наприкінці) }\end{array}$} \\
\hline & $\begin{array}{c}\text { Початок } \\
\text { експер. }\end{array}$ & $\begin{array}{c}\text { Напри-кінці } \\
\text { експер. }\end{array}$ & \multirow{2}{*}{ 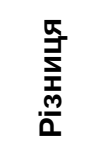 } & $\begin{array}{c}\text { Початок } \\
\text { експер. }\end{array}$ & $\begin{array}{c}\text { Напри-кінці } \\
\text { експер. }\end{array}$ & \multirow[t]{2}{*}{ 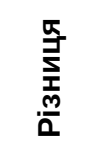 } & \\
\hline & $\%$ & $\%$ & & $\%$ & $\%$ & & \\
\hline Пасивний & 20,9 & 9,3 & $-11,6$ & 16,3 & 4,4 & $-11,9$ & $-0,2$ \\
\hline Елементарний & 32,6 & 30,2 & $-2,3$ & 36,3 & 25,2 & $-11,1$ & $-8,8$ \\
\hline Базовий & 28,7 & 33,3 & 4,6 & 29,6 & 41,5 & 11,9 & 7,2 \\
\hline Високий & 17,8 & 27,1 & 9,3 & 17,8 & 28,9 & 11,1 & 1,8 \\
\hline
\end{tabular}

Відповіді студентів контрольної та експериментальної груп на тест для визначення показника «Самоаналіз» наведено у табл. 1.

Результати експериментальної роботи показали, що провідну роль у структурі готовності бакалаврів спеціальної освіти до упровадження цифрових технологій у профресійній діяльності в умовах інклюзивного освітнього середовища відіграє мотиваційний компонент. Рівень його сформованості сприятиме підвищенню рівня й інших компонентів такої готовності. Також суттєва динаміка спостерігається і у рівні сорормованості предметного компонента.

Результати експерименту дозволяють обґрунтувати практичні рекомендації фрормування готовності бакалаврів спеціальної освіти до упровадження цифрових технологій у професійній діяльності в умовах інклюзивного освітнього середовища під час їх підготовки в педагогічному ЗВО в умовах цифрровізації освіти:

- інтеграція інфрорматики 3 загально-навчальними, професійними дисциплінами і профресійними модулями, на основі якої розроблено спеціальний курс «Цисррові технології в умовах ІОП»;

- використання інфрормаційно-освітнього середовища ЗВО, що є ресурсною базою фрормування цифрової грамотності майбутніх спеціальних педагогів;

- інтеграція фрормальної, неформальної та інфрормальної освіти, що забезпечує комплексне фрормування цифрової грамотності майбутніх спеціальних педагогів та її зв'язок з більш широким спектром знань, умінь і досвіду професійної та навчальної діяльності;

- створення і використання комплексу профресійно-орієнтованих завдань як спеціальних засобів фрормування цифррової компетентності.

Висновки. Проведення експериментальної підготовки бакалаврів освіти до упровадження цисрових технологійупрофесійній діяльностів умовах інклюзивного освітнього простору вимагало проведення педагогічного експерименту, який передбачав порівняння навчальних досягнень бакалаврів освіти контрольної та експериментальної груп. Це зумовило потребу у розробленні критеріальної бази дослідження. Було розроблено відповідно три критерії - теоретичний, практичний і психологічний. Їх показниками висту- пили здатність до розвитку у царині ЦТ для інклюзії, обсяг знань, цифрова обізнаність, уміння конструювання інклюзивного освітнього простору засобами ЦТ, самоаналіз. Педагогічний експеримент показав еорективність запропонованої експериментальної підготовки бакалаврів освіти до упровадження цифррових технологій у професійній діяльності в умовах інклюзивного освітнього простору.

Перспективними вважаємо дослідження питань запровадження в освітній процес професійної підготовки бакалаврів освіти технологій контекстного навчання, мультимедійного забезпечення курсів, організації дистанційного навчання тощо.

\section{БІБЛІОГРАФІЧНИЙ СПИСОК:}

1. Гуревич Р.С., Коломієць Т.Д. Методичні аспекти використання інорормаційно-комунікаційних технологій у навчанні. Вісник ЛНУ ім. Тараса Шевченка. 2010. № 1 (188). C. 60-67.

2. Сухобок О.Ю. Засоби інноваційних педагогічних технологій у підготовці майбутніх учителів фрізичної культури. Педагогіка, психологія та медикобіологічні проблеми фрізичного виховання і спорту. 2011. № 12. C. 109-112.

3. Druz V.A., lermakov S.S., Nosko M.O., Shesterova L.Y., Novitskaya N.A. The problems of students' physical training individualization. Pedagogics Psychology MedicalBiological Problems of Physical Training and Sports. 2017. № 21 (2). C. 51-59. doi: 10.15561/18189172.2017.0201

4. Makarenko L., Słabko W. Informatization of education in the era of globalization of educational space. Szkoła - Zawód - Praca. 2015. T. 10. P. 20-29.

5. Bates T.A.W. Teaching in a Digital Age. URL: https:// wiki.lib.sun.ac.za/images/f/f3/ Teaching-in-a-digital-age.pdf

6. Hamburg I., Bucksch S. Inclusive Education and Digital Social innovation. Advances in Social Sciences Research Journal. 2017. № 4 (5). P. 161-169. DOI: https://doi.org/10.14738/assrj.45.2861

7. Lazzari M. Digital storytelling for inclusive education: an experience in initial teacher training. Proceedings of the 10th International Conference on e-Learning (Funchal, Portugal, July 1-2, 2016). P. 199-203. URL: https://www.marcolazzari.it/publi cations/EL-lazzari-2016-sito.pdf

8. Marci-Boehncke G., Vogel T. Digital literacy and inclusion: the impact of theory and practice in teacher's education. 12th International Technology, Education and Development Conference (March, 2018). 